\title{
STABILIZATION OF RAMMED EARTH
}

\author{
Mihir vora $^{1}$, Ankit patel ${ }^{2}$, Mohammad Soyab Shaikh ${ }^{3}$ \\ ${ }^{1}$ Consultant, Geotechnical Engineering, KBM Consultancy, Gujarat, India \\ ${ }^{2}$ Assistant professor, Civil Engineering, SVBIT, Gujarat, India \\ ${ }^{3}$ Assistant professor, Civil Engineering, GEC Dahod, Gujarat, India
}

\begin{abstract}
Rammed earth is an ancient building technique used in many regions of the world. Due to the low embodied energy of the material and diminished transportation costs, rammed earth offers an economical and sustainable alternative to concrete. Along with other advantages like sustainable construction, architectural quality \& flexibility, contribution to building health and performance, ease \& speed of construction etc. The main weakness of earth as a building material lies in its low resistance to water. Overhanging eaves and verandas help considerably, but tropical rains of any intensity can damage unprotected walls. Because of the clay fraction, which is necessary for cohesion, walls built of unstabilised soil will swell on taking up water and shrink on drying. This may lead to severe cracking and difficulty in getting protective renderings to adhere to the wall. There are some issues which needs to be addressed like shrinkage, proper soil selection, low compressive strength, cracking, durability aspects etc for rammed earth construction. From the available literatures and research works done earlier, it is evident that one way to address these problems is to stabilize rammed earth with cement.
\end{abstract}

The primary objective of this study is to make use of the RHA (waste material) with NS and understand its effects on the geotechnical properties, compressive strength \& weathering. The proctor tests results indicates that with the increase in RHA percentage there was an increase in the Optimum Moisture Content (OMC) and reduction in the Maximum Dry Density (MDD). The cube compressive strength values decreased with subsequent addition of RHA to its maximum at $5 \%$ RHA. The deterioration is increases with increasing in RHA content.

Keywords: Rammed earth, Rice husk ash, OMC and MDD, Weathering

\section{ABOUT RAMMED EARTH}

Rammed earth is a construction technique where soil is taken from the ground and compacted to form structures. Removable formwork is installed, and the soil compacted within it.[1] Rammed earth has continually been reinvented as a building material. At times it has been used as a quick technique for the building of fortifications, a cheap way a man can build his own home, and a sustainable construction technique using only what is available on site.

Rammed earth buildings are found around the Mediterranean, and along the same latitude in Iran, Pakistan, India and China. Rammed earth was taken by the Europeans to South America, and many colonial buildings in parts of Brazil and Columbia are constructed in rammed earth. The rediscovery of rammed earth as a sustainable building material prompted its use in Australia and the southern United States from the early 1970s onward. Today rammed earth is receiving increased interest as sustainable construction practices become more main stream.[2]. Rammed earth constructions can be classified into two broad categories: stabilized rammed earth and un-stabilized rammed earth. Unsterilized rammed earth is made from mainly soil, sand and gravel. Whereas stabilized rammed earth contains additives like cement or lime in addition to soil, sand and gravel.

\subsection{Soil Stabilization}

The aim of soil stabilization is to increase the soil's resistance to destructive weather conditions in one or more of the following ways: [2]

1) By cementing the panicles of the soil together, leading to increased strength and cohesion.

2) By reducing the movements (shrinkage and swelling) of the soil when its moisture content varies due to weather conditions.

3) By making the soil waterproof or at least less permeable to moisture.

\subsection{Methods of Construction}

To build a traditional rammed earth wall, a formwork box is constructed using two parallel timber sides (Figure 1.1), supported on two or more horizontal timbers. Vertical timbers are then placed through holes in the ends of the horizontal timbers thereby restraining the formwork. [3]

These vertical timbers are connected at the top using rope, forming an open box. Soil is taken from the ground and if 
necessary sieved to remove larger particles. Additives such as straw or lime may be mixed into the soil, which is then dropped into the formwork in layers, usually around $150 \mathrm{~mm}$ high. The layer is then compacted using a heavy rammer. Upon compaction of one layer, another layer of earth is placed in the formwork and the process repeated until the formwork is full. The formwork is then removed and placed on the next set of horizontal timbers where the process is repeated. Completion of one horizontal level the formwork is moved vertically, the mass of standing wall being known as a lift. A rammed earth wall can thus be constructed using very little manpower and crucially without recourse to temporary works such as external scaffolding.

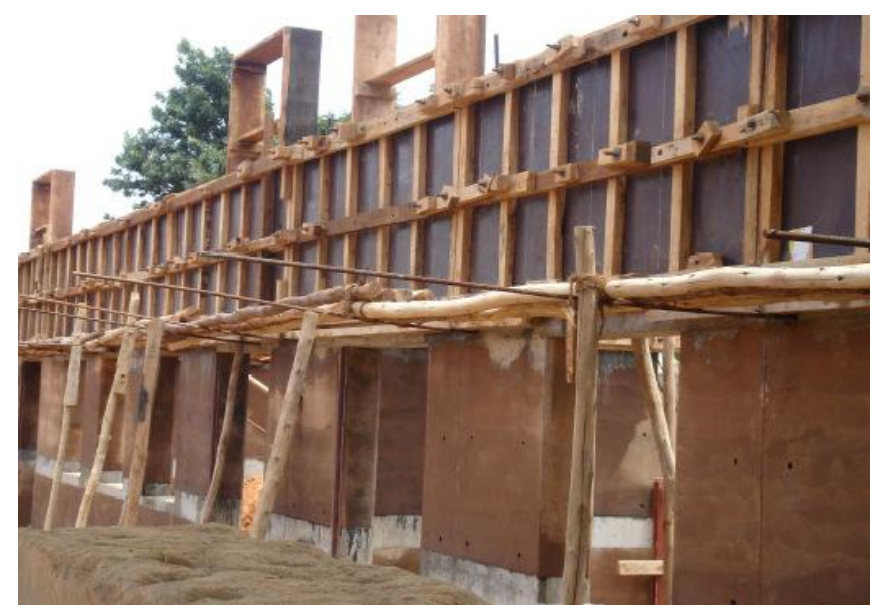

Fig -1: formwork detail [3]

\section{OBJECTIVE, SCOPE AND METHODOLOGY}

This research will draw a comparison between the NS available locally in Ahmedabad \& available literatures thereby indicating the suitability of NS for the use of RE. Since there are very few guidelines available for rammed earth when combined with a waste material like RHA

The primary objective of this study is to make use of the RHA (waste material) with NS and understand its effects on the geotechnical properties, compressive strength \& weathering. The study also intends to quantify the amount of RHA to be added to the NS according to the values of soil properties measured, in order to enhance the properties of rammed earth.

\subsection{Methodology}

Establishing properties of locally available natural soil and comparing it with properties of soil suitable for rammed earth construction as per published literature.

Effect of RHA on following properties of natural soil. The varying proportion of RHA is $5 \%, 10 \%$ and $15 \%$

Geotechnical Properties

Grain Size Distribution,
Plastic Index,

Shrinkage,

Swelling,

Compressive Strength

Dry Density and Moisture Content etc.

Weathering Effect

Unconfined Compressive Strength (UCS),

Cube Compressive Strength,

Spray Test.

From above methodology quantify the amount of RHA for batter results.

\section{MATERIAL}

\subsection{Natural Soil}

Two different sites were investigated near Ahmedabad for the selection of NS sample. SC type of soil, falling in the range of Sand \& Gravel: $45-80 \%$, Silt: $10-30 \%$, Clay: $5-20 \%$, LL< $45 \%$ \& PI: 2 - 30 (Peter Walker et al, 2005) was selected. The established detailed geo technical properties of Natural Soil has been mentioned in table -3 and $4[3]$

\subsection{Rice Husk Ash (RHA)}

Rice husk is an agricultural waste obtained from paddy. For every 4 tons of rice, 1 ton of husk is produced. About 108 tons of rice husks are generated annually in the world. The husk is disposed off either by dumping it in an open heap near the mill or site or near the roadside to be burnt later. Burning the rice husk generates about 15\%-20\% of its weight as ash. Being very light in weight, this ash results in water and air pollution.

This Rice Husk Ash (RHA) is a great environment threat causing damage to the land and the surrounding area in which it is dumped. The normal method of conversion of rice husk into ash is incineration. Generally in India husk is used as fuel in the rice mills to generate steam for the parboiling process. The quality of ash is greatly influenced by the method of its combustion (whether it is completely burnt or partially burnt). The high percentage of siliceous material in rice husk ash indicates that it has potential pozzolonic properties.RHA used for the study was manufactured at Bavla. Paddy was separated into husks and

grains. This separated husk was used as a fuel for boiling rice grains in the boiler, thereby producing ash as a by-product. The temperature maintained in the boilers was about $600-7000 \mathrm{C}$.

The ash used for the experiment was in the amorphous form having the chemical composition shown in Table 1.The chemical properties obtained for RHA shows presence of high amount of silica, $\mathrm{A} 12 \mathrm{O} 3$ and $\mathrm{Fe} 2 \mathrm{O} 3$, thereby confirming it to be a good pozzolonic material. 
Table -1: Chemical composition of RHA

\begin{tabular}{|l|l|}
\hline \multicolumn{1}{|c|}{ Constituent } & \multicolumn{1}{c|}{ Composition (\%) } \\
\hline $\mathrm{Fe} 2 \mathrm{O} 3$ & 0.10 \\
\hline $\mathrm{SiO} 2$ & 91.43 \\
\hline $\mathrm{MgO}$ & 0.07 \\
\hline $\mathrm{SO} 3$ & 0.05 \\
\hline $\mathrm{Al} 2 \mathrm{O} 3$ & 2.01 \\
\hline Loss on Ignition (LOl) & 4.28 \\
\hline
\end{tabular}

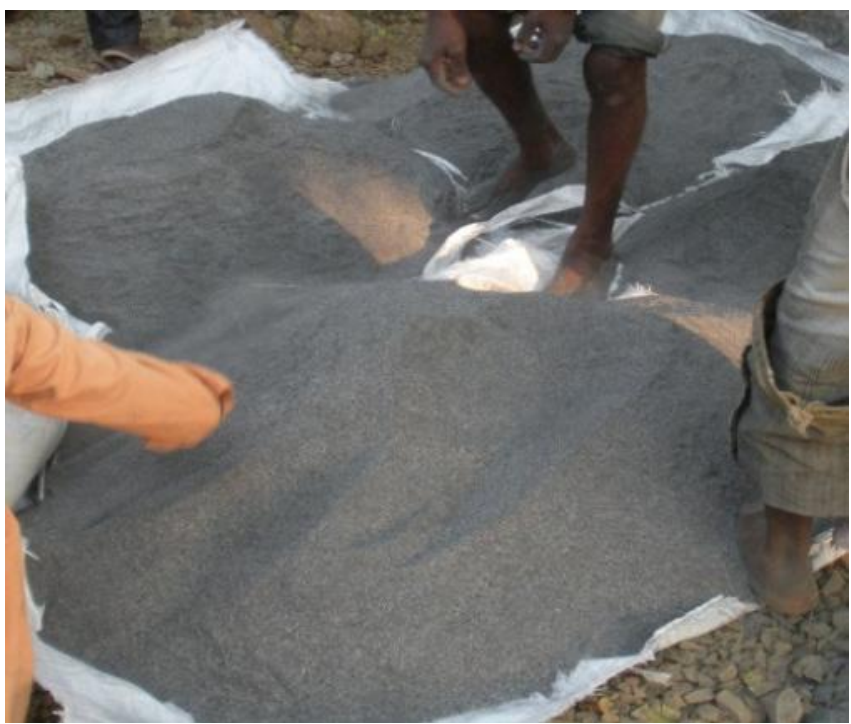

Fig -2: Rice husk ash (RHA)

\subsection{Test Procedure for Establishing Soil Properties}

For quantify the amount of RHA for batter results of rammed earth construction different test are carried out. These all tests are listed in below table 2 with reference codes[5]

Table -2: List of test

\begin{tabular}{|l|l|}
\hline Properties & Reference code \\
\hline Grain Size Analysis & IS 2720 (part 4) 1985 \\
\hline Atterberg's Limits & IS 2720 (Part 5) 1985 \\
\hline Standard Proctor Test & IS: 2720 (Part 7) 1985 \\
\hline UCS of Cylinders & IS 2720 (Part 10)-1991 \\
\hline Linear Shrinkage & IS 2720 (Part 20)-1992 \\
\hline $\begin{array}{l}\text { Free Swell Test (Spray } \\
\begin{array}{l}\text { Weathering IS 1725 1982 } \\
\text { Test) }\end{array}\end{array}$ \\
\hline
\end{tabular}

\subsection{Sample for UCS and Compressive Strength}

Fig-3 shows the sample for UCS test and Fig-4 Shows the sample for Cube compressive strength test and spray test. Sample is made with varying proportion of RHA as given below.[6]

- $95 \% \mathrm{NS}+5 \%$ RHA

- $90 \% \mathrm{NS}+10 \%$ RHA

- $85 \% \mathrm{NS}+15 \%$ RHA

For UCS test Cylindrical specimens of $38 \mathrm{~mm}$ diameter and 76 $\mathrm{mm}$ height were prepared considering IS:2720 (Part 10) as reference. For Cube $150 \mathrm{~mm}$ X $150 \mathrm{~mm}$ X $150 \mathrm{~mm}$ size cubes were casted for the all proportion as per IS 10086 .

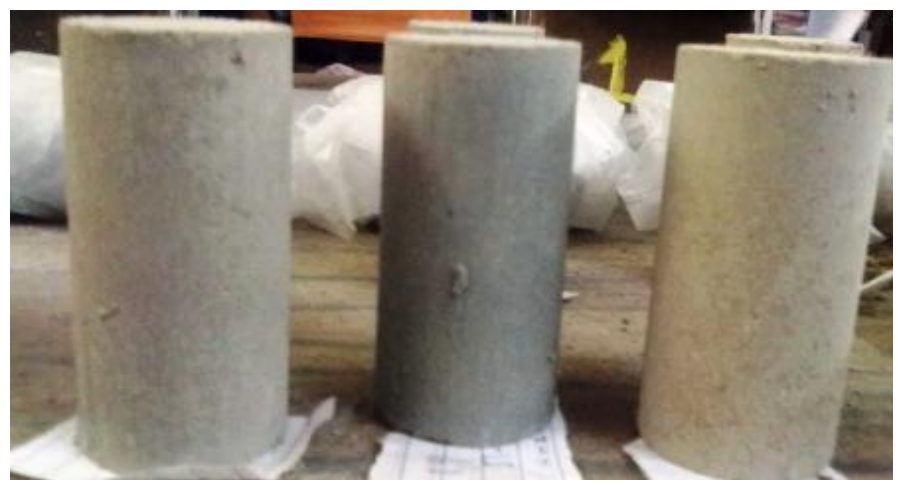

Fig -3: Sample for UCS test

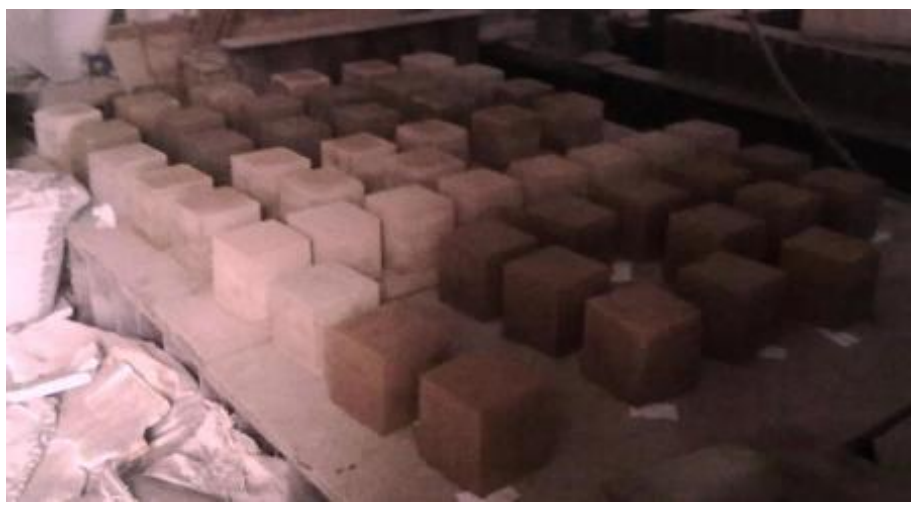

Fig -4: Sample for Compressive strength test and spray test

\section{RESULTS AND INTERPRETATION}

Table -3: Grain size analysis [4]

\begin{tabular}{|l|l|l|l|l|}
\hline & $100 \%$ NS & $5 \%$ RHA & $10 \%$ RHA & $15 \%$ RHA \\
\hline Gravel & 4 & 1 & 1 & 2 \\
\hline Coarse sand & 4 & 3 & 2 & 4 \\
\hline Medium sand & 26 & 37 & 35 & 33 \\
\hline Fine sand & 36 & 37 & 34 & 30 \\
\hline Silt +clay & 30 & 22 & 28 & 31 \\
\hline
\end{tabular}


Table -4: Atterberg's limit[5]

\begin{tabular}{|l|l|l|l|l|}
\hline & $100 \%$ NS & $5 \%$ RHA & $10 \%$ RHA & 15\%RHA \\
\hline Liquid limit & 26 & 29 & 31 & 33 \\
\hline Plastic limit & 15 & 17 & 19 & 21 \\
\hline $\begin{array}{l}\text { Plasticity } \\
\text { index }\end{array}$ & 11 & 12 & 12 & 12 \\
\hline
\end{tabular}

From table -3 and 4 the test results obtained for $100 \%$ NS indicated that the classification of soil as SC as per Unified Classification System and confirms to desirable properties for soil for rammed earth as per available literature. From above results the liquid limit is increased as percentage of RHA increases it helps to increase weathering test.

Further investigation is based on durability or weathering test and compressive strength of cube and cylinder. From this all results find out the best proportion in terms of strength and durability.

\subsection{Compaction Characteristics of NS+RHA}

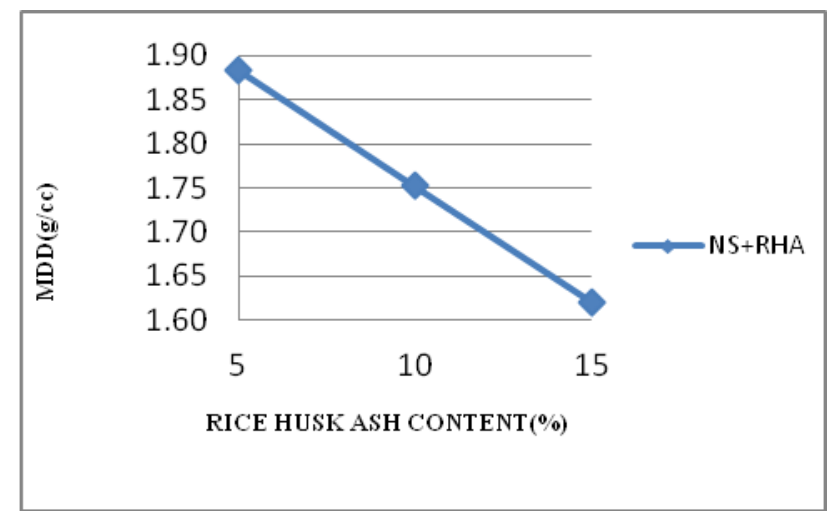

Fig -5: MDD (g/cc) versus RHA (\%)

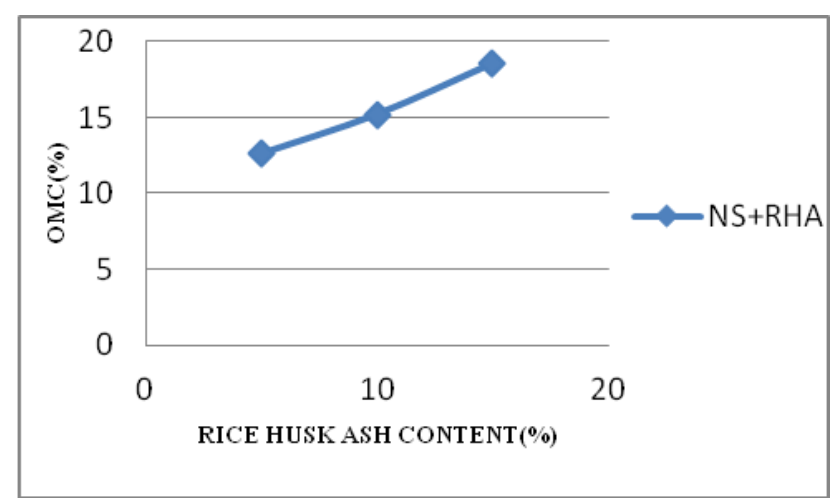

Fig -6: OMC (\%) versus RHA (\%)

The proctor tests results shown in the Figure 5 and 6 indicated that with the increase in RHA percentage there was an increase in the Optimum Moisture Content (OMC). It was also observed that with the increase in RHA percentage there was a reduction in the Maximum Dry Density (MDD)

\subsection{Unconfined Compressive Strength of NS+RHA}

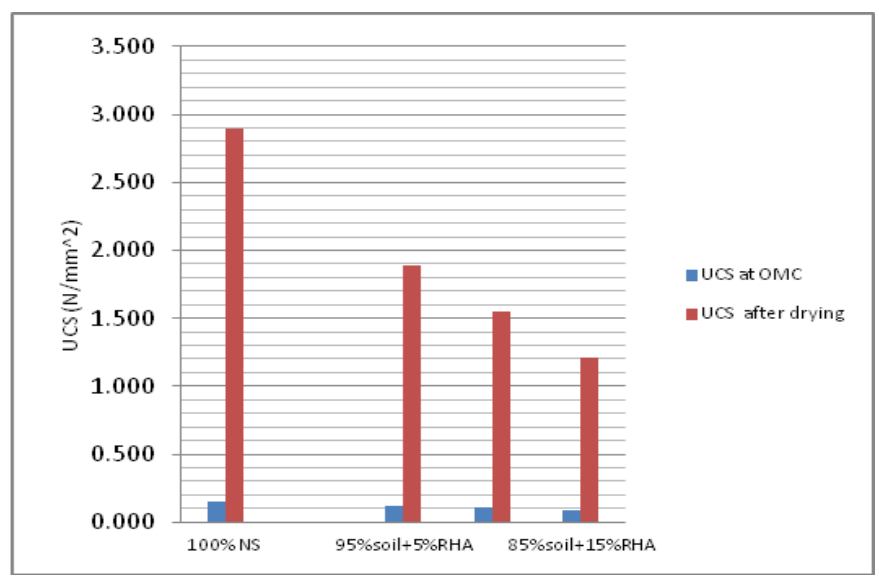

Fig -7: Unconfined compressive strength of NS+RHA

The UCS values decreased with subsequent addition of RHA to its maximum at 5\% RHA. As shown in Figure 7. Decreasing in UCS value may be due to the excess RHA introduced to the soil and therefore forming weak bonds between the soils. The above test was carried out for different moisture content one is at $\mathrm{OMC}$ and another is after draying.

\subsection{Compressive Strength of NS+RHA}

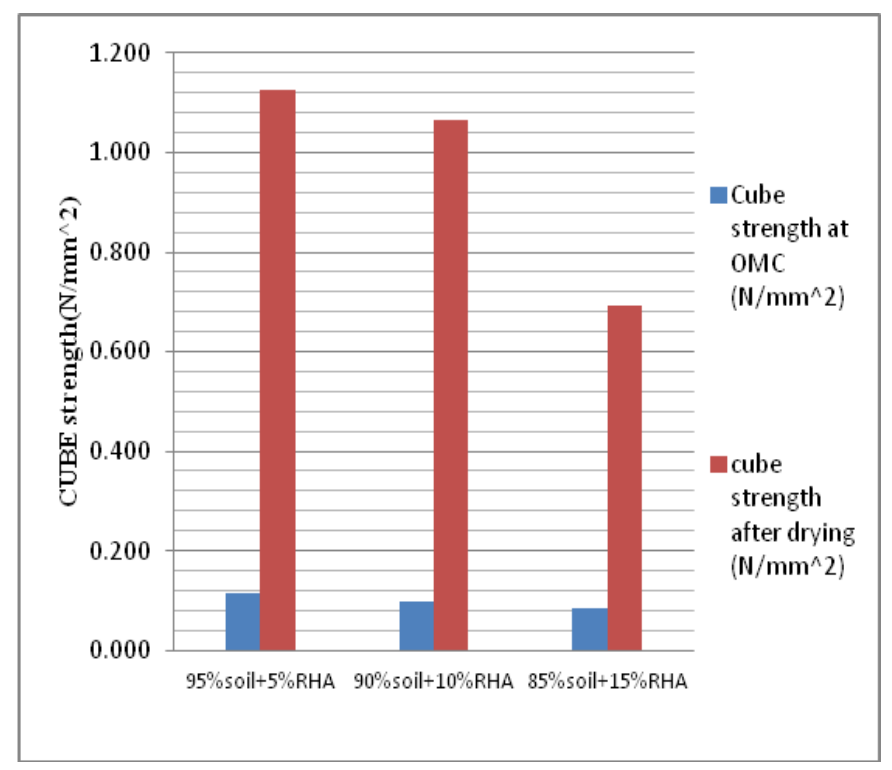

Fig -8: Compressive strength of NS+RHA

The cube compressive strength values decreased with subsequent addition of RHA to its maximum at 5\% RHA as shown in Figure 8 


\subsection{Weathering Test}

Table -5: Results of spray test

\begin{tabular}{|l|l|l|l|}
\hline $\begin{array}{l}\text { PROPORTIO } \\
\text { N }\end{array}$ & $\begin{array}{l}\text { TIME } \\
\text { TAKEN(mi } \\
\text { n) FOR } \\
\text { TEST }\end{array}$ & $\begin{array}{l}\text { DETERI } \\
\text { ORATIO } \\
\text { N }(\%)\end{array}$ & TYPE \\
\hline NS & 45 & 95 & $\begin{array}{l}\text { DISINTEGRATI } \\
\text { ON }\end{array}$ \\
\hline $\begin{array}{l}5 \% \text { RHA+95\% } \\
\text { NS }\end{array}$ & 40 & 95 & $\begin{array}{l}\text { DISINTEGRATI } \\
\text { ON }\end{array}$ \\
\hline $10 \%$ & & 95 & $\begin{array}{l}\text { DISINTEGRATI } \\
\text { ON }\end{array}$ \\
\hline RHA+90\% NS & 35 & 95 & DISINTEGRATI \\
RHA+85\% NS & 21 & 95 & ON \\
\hline
\end{tabular}

As shown in table 5 as percentage of RHA increase the deterioration time decreases. In other word RHA have poor bonding strength

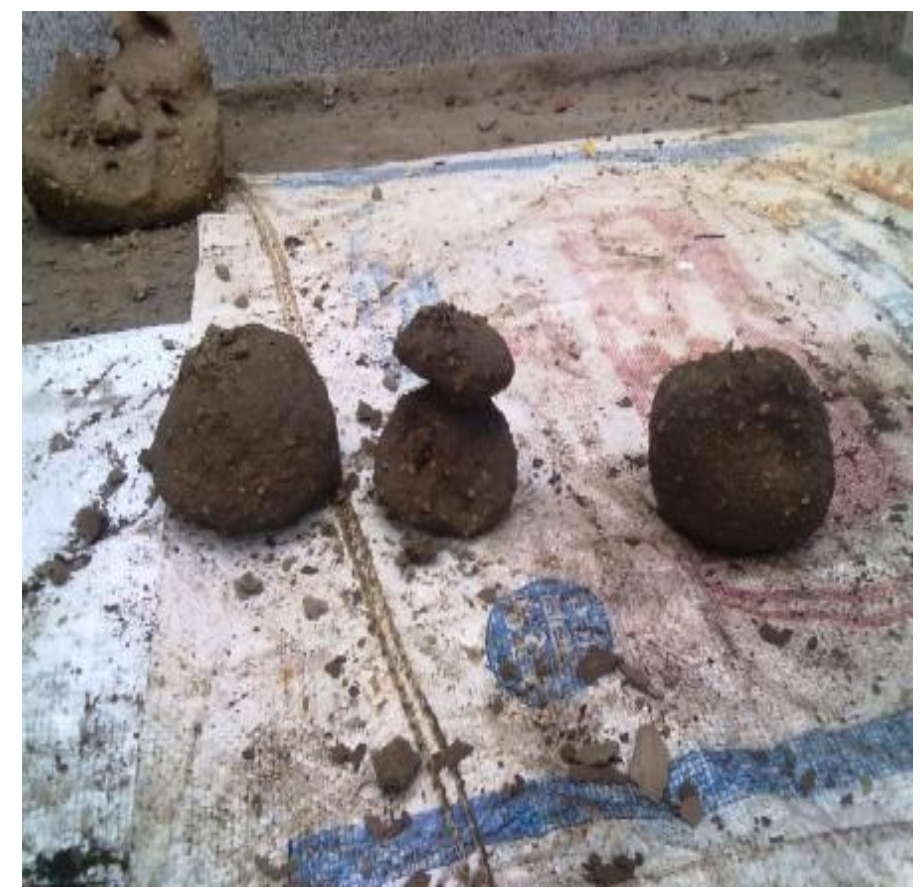

Fig -9: Specimen after spray test

\section{CONCLUSIONS}

There was a decrease in the MDD on addition of RHA. There was an increase in the Optimum Moisture Content (OMC) from $9.84 \%$ to $19 \%$ on addition of RHA.The decrease in the MDD can be attributed to the replacement of soil and by the RHA in the mixture which have relatively lower specific gravity compared to that of the soil.
Also since RHA has a low specific gravity \& is inherently a weaker material than NS, there is reduction in the UCS values. From table 5. it was observed that when spray test was conducted on $100 \%$ N.S. sample the soil sample disintegrated in $45 \mathrm{~min}$ whereas when weathering test was conducted on N.S. + varying \% of RHA $(5 \%, 10 \%, 15 \%)$ cubes, the sample had disintegrated in 20 to $30 \mathrm{~min}$. There is a reduction in compressive strength when RHA is added to NS due to the lack of formation of cementation compounds so addition of cement or lime is must required for stabilization of rammed earth.

\section{ACKNOWLEDGEMENTS}

I am obliged to Mr. Mihir Vora for permitting the use of KBM laboratory for the experiments. I am also grateful to the people at KBM \& CEPT laboratory i.e. Hari bhai, Kanjhi bhai, Raju Bhai, Vijay Bhai \& Mr Bhargav Tewar for their support during the experimental process and last but not the least, I am thankful to the almighty to bless me with such supportive parents, in laws, siblings and Megha Patel for always being there for me.

\section{REFERENCES}

[1]. Paul Jaquin PhD Thesis Appendix A - Historic rammed earth distribution

[2]. Prasanna Kumar P, "Stabilised Rammed Earth for Walls: Materials, Compressive Strength and Elastic Properties", Department of Civil Engineering. IISc, Bangalore, July 2009

[3]. Peter Walker, Rowland Keable, Joe Martin, and Vasilios Maniatidis., "Rammed earth design and construction guidelines", BRE Bookshop Publications, UK, 2005

[4]. I.S: 1905 - 1987(reaffirmed 1988), "Code of Practice for Structural Use of Unreinforced Masonry",Bureau of Indian Standards, New Delhi, India.

[5]. SP: 36 (Part I) - 1987,

[6]. SP: 36 (Part II) - 1988 (reaffirmed 1995), "Field Testing of Soils for Civil Engineering Purposes",

[7]. IS 1498-1970, "Classification and Identification of soil for general engineering purpose".

[8]. IS 1725-1982, "Specification for soil based blocks used in general building construction".

[9]. IS 2720 (Part 10)-1991, "Method of Test for Soil (Determination of UCS)"'.

[10]. IS 2720 (Part 20)-1992, "Method of Test for Soil (Determination of Linear Shrinkage)".

[11]. IS 2720 (Part 4)-1985, "Method of Test for Soil (Grain Size Analysis)".

[12]. IS 2720 (Part 40)-1977, "Method of Test for Soil (Determination of Free Swell Index)".

[13]. IS 2720 (Part 5)-1985, "Method of Test for Soil (Determination of LL and PL)". 


\section{BIOGRAPHIES}

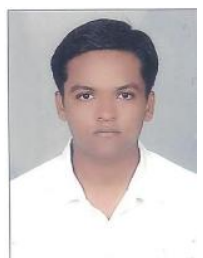

Mr.Ankit patel, Assistant professor ,Svbit. He has experience of about 2 years in teaching,he has guided more than 15 students of UG program in different field like - rain water harvesting ,concrete technology and geotechnical engineering etc.... 